\title{
PENGGUNAAN DIGITAL MARKETING DALAM PEMBANGUNAN DESA CATUR KINTAMANI MENGWI
}

\author{
${ }^{1}$ Dr. I Wayan Ruspendi Junaedi, SE., MA., ${ }^{2}$ Dr. I Gusti Bagus Rai Utama, SE., MMA., \\ M.A, ${ }^{3}$ Dr. Dermawan Waruwu, M.Si \\ ${ }^{123}$ Universitas Dhyana Pura \\ 1uspendijunaedi@undhirabali.ac.id, ${ }^{2}$ raiutama@undhirabali.ac.id, ${ }^{3}$ dermawanwaruwu@undhirabali.ac.id \\ Koresponden Author: ruspendijunaedi@undhirabali.ac.id
}

\begin{abstract}
Abstrak
Permasalahan yang ditemukan bahwa (1) Belum tersedianya pusat informasi tempat wisata, (2) Belum terintegrasi wilayah untuk dapat dijadikan sebagai potensi wisata. (3) belum adanya pusat pembuatan konten menarik mengenai promosi budaya, produksi pertanian, dan wisata. (4) Belum ada pengelolaan digital marketing untuk desa wisata Catur Kintamani. Untuk mengatasi masalah tersebut, tujuan program PKM adalah sebagai berikut: (1). Sosialisasi potensi wisata dengan tersedianya informasi center, (2). Mengintegrisakan seluruh komponen potensi desa dalam satu program desa wisata, (3).Pembuatan media promosi (content) sebagai bahan digital marketing, dan (4). Pelatihan pemasaran digital sebagai bahan promosi kepada biro perjalanan dan calon wisatawan. Metode pelaksanaan Program PKM antara lain: sosialisasi awal, pendampingan, pelatihan, monitoring, evaluasi, dan keberlanjutan program, yang dilakukan oleh tim pengusul serta dibantu oleh tenaga ahli dan mahasiswa dari Universitas Dhyana Pura. Hasilnya adalah Desa Catur memiliki pengetahuan, keterampilan tentang (1). Adanya potensi wisata dengan tersedianya informasi center, (2). Ada integrasi seluruh komponen potensi desa dalam satu program desa wisata, (3). Ada media promosi (Website) sebagai bahan digital marketing, dan (4). Memiliki pengetahuan pemasaran digital sebagai bahan promosi. Tim pelaksana dan setiap kelompok melaporkan hasilnya dengan cara presentasi dan dokumentasi. Keberlanjutan dari program ini adalah masyarakat terus belajar dan tim PKM Undhira mendampingi kelompok dalam meningkatkan kesejahteraannya.
\end{abstract}

Kata Kunci: Desa Catur Kintamani, Digital marketing, Visitor center, Wisata Alam. 


\section{PENDAHULUAN}

Program Kemitraan Masyarakat (PKM) Penggunaan digital marketing ini dilaksanakan di Desa Catur Kintamani yang berlokasi di kecamatan Kintamani, Kabupaten Bangli, Bali. Desa Catur yang secara Adminitratif dipimpin oleh Seorang Perbekel (Kepala Desa) yang dipilih secara Demokasi dan menaungi tiga Banjar yakni Catur, Lampu dan Mungsengan.

Adapun batas - batas Desa Catur yaitu:

1. Sebelah Timur berbatasan dengan Desa Belantih, Kecamatan Kintamani, Kabupaten Bangli

2. Sebelah Barat berbatasan dengan Desa Tambakan, Kabupaten Buleleng

3. Sebelah Utara berbatasan dengan Desa Pengejaran, Kecamatan Kintamani, Kabupaten Bangli

4. Sebelah Selatan berbatasan dengan Desa Belok Sidan, Kabupaten Badung.

Struktur perekonomian Desa Catur Kintamani masih bercorak agraris yang menitik beratkan pada sektor pertanian, hal ini didukung oleh penggunaan lahan pertanian masih mempunyai porsi yang tersebar sebanyak $85 \%$ dari total penggunaan lahan Desa, juga sekitar $80 \%$ mata pencaharian Penduduk menggantungkan hidup pada sektor pertanian. Pada sektor pertanian ini komoditi yang menonjol sebagai primadona atau andalan adalah komoditas Kopi dan Jeruk. Beberapa sektor ekonomi yang tergolong Economic Base disamping sektor pertanian adalah: (1) Wisata Agro, (2) Wisata Alam, (3) Wisata Budaya/Religi, (4) Wisata Herbal dan, (5) Pasar Agro Hultikultural. Pada sektor jasa yang menonjol adalah timbulnya lembaga keuangan mikro berupaya koperasi dan LPD sebagai pendukung ekonomi Desa. Hal ini diharapkan akan membawa dampak positif dalam perkembangan ekonomi Desa secara keseluruhan.

\subsection{Analisis Permasalahan}

Secara keseluruhan, pengelola daya tarik wisata Desa Catur Kintamani sedang mengalami permasalahan pemasaran yang nampak dari minimnya tingkat kunjungan, dan masalah aksesibilitas karena jarak Desa Catur Kintamani yang tergolong cukup jauh dari Pusat Kota Denpasar kemudian jauhnya dari pusat wisata yang biasa dikunjungi oleh wisatawan membuat wilayah catur kintamani tidak banyak pengunjung. Permasalahan ini dipercaya dapat diatasi dengan penyediaan brosur online dalam bentuk digital marketing yang terdiri dari website, media sosial, dan penggunaan influencer. Selain itu menyediakan program/paket wisata agar para wisatawan lebih tertarik untuk menginap di desa tersebut, tidak sekedar berkunjung singgah saja.

Penelitian sebelumnya yang dilakukan oleh kampus undhira mengenai pendampingan terhadap desa wisata catur kintamani ini menemukan bahwa pada tahun 2016 masih kurangnya penggunaan media sosial. PKM 2016 juga menghasilkan beberapa kegiatan pertama dibuatkannya Tim membuat promosi destinasi wisata secara visualisasi melalui media sosial dengan tautan facebook.com/ caturkintamanivillage dan instagram.com/ caturkintamanivillage. Selain itu PKM tahun 2016 juga menghasilkan logo pariwista kintamani dan juga pembuatan $\mathrm{x}$ banner.

Identifikasi masalah yang telah dilakukan menyimpulkan bahwa (1) Belum tersedianya pusat informasi tempat wisata, (2) Belum terintegrasi wilayah untuk dapat dijadikan sebagai potensi wisata. (3) belum adanya pusat pembuatan konten menarik mengenai promosi budaya, produksi pertanian, dan wisata. (4) Belum ada pengelolaan digital marketing untuk desa wisata Catur Kintamani

Untuk mengatasi masalah tersebut, masyarakat Desa Catur Kintamani memerlukan solusi berupa program PKM dalam bentuk kegiatan sebagai berikut:

Teknologi Tepat Guna | 218 
1) Sosialisasi potensi wisata dengan tersedianya informasi center.

2) Mengintegrisakan seluruh komponen potensi desa dalam satu program desa wisata,

3) Pembuatan media promosi (content) sebagai bahan digital marketing,

4) dan Pelatihan pemasaran digital sebagai bahan promosi kepada biro perjalanan dan calon wisatawan. Penggunaan media sosial yang berkelanjutan sebagai bahan promosi desa wisata

\section{TUJUAN DAN SASARAN}

\section{Tujuan Kegiatan}

Untuk melestarikan sebuah desa wisata maka salah satu caranya adalah dengan cara menambah kunjungan wisatawan. Karena dengan banyaknya wisatawan yang datang berkunjung ke wilayah tersebut maka warga akan memiliki kesadaran akan lingkungan dan budayanya.

\section{Sasaran Kegiatan}

Sasaran kegiatan PKM Penggunaan Digital Marketing dalam Pengembangan Desa Catur adalah sebagai berikut:

\section{Belum tersedianya pusat informasi tempat wisata:}

1) Menyelenggarakan sosialisasi tentang pentingnya visitor center sebagai pelayanan informasi kepada wisatawan maupun calon wisatawan. Kemudian dengan menambahkan pemberi informasi menggunakan bilingual karena sejauh ini bali selalu dikunjungi oleh wisatawan asing.

2) Media center juga bekerjsama dengan pihak yang lebih berwenang dalam pariwisata untuk memberikan informasi seperti dinas pariwisata, kemudian juga informasi-informasi akses menuju wilayah Catur Kintamani.
4. Mengintegrisakan seluruh komponen potensi desa dalam satu program desa wisata.

1). Membuat Peta wisata yang sudah terintegrasikan dan wilayah serta produk mana saja yang sudah layak untuk di masukan kedalam potensi wisata.

2). Membuat kesepakatan bersama mengenai harga dan produk apa saja yang bisa dikaitkan antara satu wisata dengan wisata lainnya.

1) Rebranding ulang sesuai kebutuhan wisata sekarang seperti pintu masuk ke desa wisata, tersedia spot photo yang menarik dan pembuatan paket wisata untuk desa Catur Kintamani.

2. Pembuatan media promosi (content) sebagai bahan digital marketing.

1) Pelatihan pembuatan video yang menarik sebagai destinasi wisata.

2) Pelatihan Photographi yang melibatkan anak-anak muda yang berada di desa Kintamani.

3) Membuat Flyer, Banner, Insta story, video testimony, dan akses peta menuju wisata kintamani.

3. Belum ada pengelolaan digital marketing untuk desa wisata Catur Kintamani.

1) Pelatihan promosi menggunakan media sosial, menggunakan sistem push promoted, Sponsored, google ads, dan juga penggunaan hashtag media sosial.

2) Menggunakan Influencer baik lokal influencer, celebgram, serta artis yang sudah terkenal sebagai bagian dari endorsment wilayah.

3) Pelatihan media sosial dengan tag tokoh-tokoh penting atau posting video testimony dari para pengunjung (wisatawan).

\section{METODE PELAKSANAAN}


Metode pelaksanaan Program Kemitraan Masyarakat (PKM) Penggunaan digital marketing ini dijelaskan dibawah ini yang terdiri dari sosialisasi, pelatihan, pendampingan, monitoring, evaluasi dan keberlanjutan program yang bertujuan meningkatkan aspek pengetahuan dan keterampilan para Penggunaan digital marketing Desa Catur Kintamani.

\section{MANFAAT YANG DIPEROLEH (OUTCOME)}

\section{Dampak ekonomi dan sosial}

Kegiatan Program Kemitraan Masyarakat pada Tim Pemuda Digital Marketing mendapat dukungan dari berbagai pihak yaitu Universitas Dhyana Pura dan mitra Kepala Desa Catur, Pemuda Digimart Desa Catur, PKK dan Pokdarwis. Pelaksanaan program adalah sebagai berikut:

1. Tahap Sosialisasi Program Kemitraan Masyarakat (PKM) Penggunaan digital marketing.

2. Pelatihan dan pendampingan tentang pentingnya Pusat Informasi Visitor Center

3. Pelatihan Integrasi seluruh komponen potensi desa dalam satu program desa wisata.

4. Pelatihan dan pendampingan mengenai pembuatan web dan cara pemasaran online.

5. Pelatihan dan pendampingan Tari Tradisional dan kontenporer

6. Pelatihan Fotografi dan Penggunaan Digital Marketing (DIGIMART)

7. Penyerahan Bantuan Alat, berupa Laptop Asus, Modem, Papan Nama Pusat Informasi dan Bak Sampah.

8. Tahap pendampingan PKM

9. Tahap Monitoring

10. Tahap Evaluasi

Pelatihan dan pendampingan tentang pentingnya Pusat Informasi Visitor Center

Tim pelaksana PKM memberikan pelatihan dan pendampingan kepada anggota Kelompok Pemuda digital Maketing maupun Kelompok Sadar Wisata (Pokdarwis) di Desa Catur tentang sosialisasi pentingnya visitor center sebagai pelayanan informasi kepada wisatawan maupun calon wisatawan. Kemudian dengan menambahkan pemberi informasi menggunakan bilingual karena sejauh ini bali selalu dikunjungi oleh wisatawan mancanegara dan wisatawan Nusantara. Gambar 1. di bawah ini adalah Kegiatan PKM dalam penyerahan Papan Nama Pusat Informasi (Visitor Centre) Desa Wisata Catur dan Sekaligus Pemasangan Papan Nama Pusat Informasi (Visitor Centre), bersama Sekretaris Desa dan perangkat Desa Catur Kintamani, Bangli, Bali, untuk masyarakat tahu bahwa pentingnya pusat informasi tersebut buat wisatawan, baik Nusantara maupun Mancanegara.

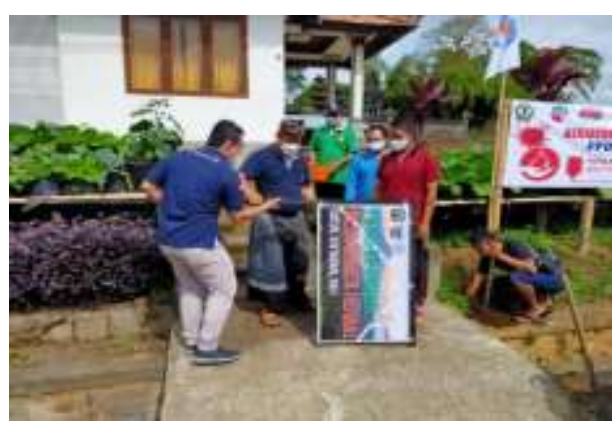

Gambar 1. Penyerahan sekaligus
pemasangan Papan Nama Pusat
Informasi (Visitor Centre).

Media center juga bekerjsama dengan pihak yang lebih berwenang dalam pariwisata untuk memberikan informasi seperti dinas pariwisata, kemudian juga informasi-informasi akses menuju wilayah Catur Kintamani. Grafik 1 dibawah adalah menunjukan peningkatan kemapuan warga desa catur sebelum dan sesudah sosialisasi tentang pusat informasi (visitor centre). 


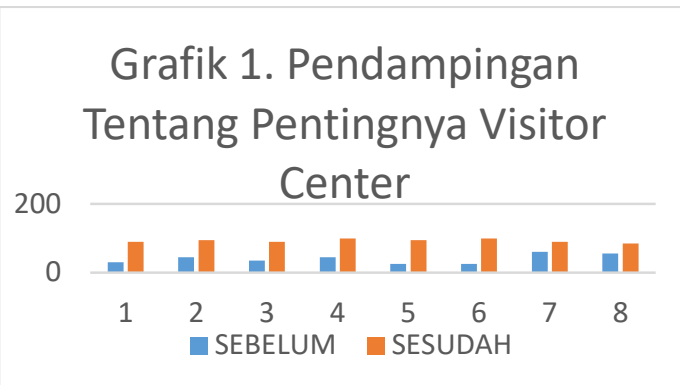

\section{Grafik 1. Sosialisasi dan Pelatihan Pusat Informasi (visitor centre)}

\section{Pelatihan Integrasi seluruh komponen potensi desa dalam satu program desa wisata.}

Mengintegrisakan seluruh komponen potensi desa dalam satu program desa wisata. Membuat Peta wisata yang sudah terintegrasikan dan wilayah serta produk mana saja yang sudah layak untuk di masukan kedalam potensi wisata. Membuat kesepakatan bersama mengenai harga dan produk apa saja yang bisa dikaitkan antara satu wisata dengan wisata lainnya. Sehingga paket-paket wisata yang sudah ada ini bisa diimplementasikan integrasi potensi wisata ini. Secara umum Desa Catur memiliki keunggulan pada sektor agrowisata, tanaman herbal, budaya, dan keindahan alamnya. Hal ini didukung dengan adanya Air Terjun Segeha (Air Terjun Kembar) yang terletak di Subak Tri Karyanadi dan Subak Tiying Seni. Potensi wisata alam ini didukung dengan budaya yang unik. Masyarakat Desa Catur memiliki 21 pura yang tersebar di tiga banjar dan 8 subak. Penduduk Desa Catur terdiri atas 2 etnis yaitu etnis Bali (Hindu) dan etnis Tionghoa (Budha dan Kong $\mathrm{Hu} \mathrm{Chu}$ ). Secara khusus di Subak Lalang anggota masyarakatnya sekitar $75 \%$ etnis Tionghoa. Walaupun di Desa Catur tidak ada Vihara, namun di salah satu pura terlihat perpaduan budaya Bali dan Tionghoa di Pura Penyagjagan. Dalam Pura Penyagjagan ini terdapat sebuah Kongco (tempat sembahyang umat Buddha dan Kong $\mathrm{Hu} \mathrm{Chu}$ ). Kehidupan masyarakat Catur terjalin kerja sama dan keharmonisan yang dipadu dengan budaya Bali dan Tionghoa.

Dengan terintegrasinya potensi-potensi wisata ini maka Tim PKM undhira membuat flyer dan brosur sebagai salah satu bagian promosi digital marketing (manajemen pemasaran) Desa Catur.

Informasi yang tim PKM dapatkan dari kepala desa dan masyarakat Desa Catur bahwa sudah ada Paket wisata. Paket wisata yang ditawarkan kepada wisatawan berdasarkan daya tarik wisata yang tersedia, antara lain:

1. Paket 1: Wisatawan disuguhkan minuman herbal seperti teh cascara, teh daun kopi, teh daun piduh, sereh, kopi, kudapan pangan lokal, dan lain-lain.

2. Paket 2: Wisatawan diberikan kelas pengenalan jenis dan manfaat tanaman herbal dalam bahasa Indonesia dan Inggris. Pengenalan jenis-jenis tanaman herbal serta proses pembuatan produk herbal dapat dilihat melalui TV 36 inch yang diberikan oleh tim PPDM.

3. Paket 3: Wisatawan makan siang dengan menu pangan tradisional yang memiliki manfaat bagi kesehatan serta diambil dari kebun masyarakat.

4. Paket 4: Wisatawan melakukan perjalanan wisata atau trekking ke air terjun, sumber mata air suci, dan kebun herbal. Pada saat trekking di kebun kopi dan jeruk, wisatawan dapat memetik kopi atau jeruk secara langsung dan gratis di jalur trekking tersebut.

5. Paket 5: Setelah pulang dari trekking, wisatawan diberikan pelayanan spa dan akupresur dengan menggunakan produk herbal dari KWT untuk memulihkan kondisi fisik wisatawan.

6. Paket 6: Akomodasi homestay telah tersedia sebanyak 8 homestay atau 24 kamar tidur dengan suasana pedesaan yang sejuk karena Desa Catur berada pada ketinggian 1.250 meter dari permukaan laut dan suhu sekitar $18-20$ derajat Celsius. Paket wisata inilah yang di integrasikan dengan digital marketing Tim PKM Undhira.

Grafik 2. Dibawah ini menunjukan peningkatan pengetahuan sebelum dan setelah pelatihan warga desa catur tentang integrasi potensi- 
potensi wisata desa catur menjadi paket - paket wisata yang akan di buat flyer dan brosur oleh Tim PKM Undhira, setelah PPKM Darurat ini selesai. Karena kami tim PKM agak susah untuk bisa dating memberikan lanjutan karena pandemic covid -19 meningkat tajam di Bali.

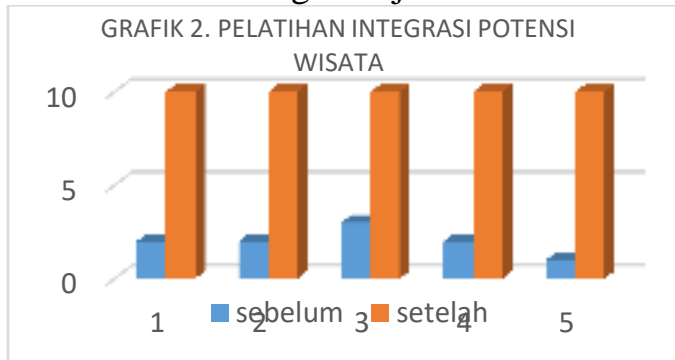

(Sumber: Analisis Tik PKM, 2021)

Jika dilihat grafik 2 diatas maka jelas terlihat ada peningkatan rata-rata $55-60 \%$ selisih sebelum dan sesudah pelatihan integrasi potensi wisata desa. Namun ada kendala bahwa Tim belum bisa mengintegrasi potensi-potensi wisata tersebut dalam satu bentuk Flayer dan brosur, karena ada Pemberlakuan Pembatasa Kegiatan Masyarakat (PPKM) Darurat. Semoga setelah PPKM berlalu kami bisa merealisasikan rencana kami.

\section{Pelatihan Tari oleh Tim UKM Undhira Pemudi Desa Catur}

Disamping itu juga diadakan pelatihan tari untuk adik-adik pemudi desa Catur, Kintamani, baik tradisional maupun tari kontenporer oleh Unit Kegiatan Mahasiswa Universitas dhyana Pura (Mileni, Evi dan kawan-kawan) yang disiapkan dalam penyambutan tamu saat ada kunjungan wisatawan. Mengapa hal ini penting dalam pembuatan konten di media sosial? Jika ada kegiatan pentas di Desa Catur dan ada dokumentasi dari Tim Pemuda Digimart, maka dokumentasi tersebut yang akan kita posting, buat konten dan endorse untuk dilakukan sehingga mempromosikan Desa wisata Catur, untuk wisatawan datang dan tinggal stay bersama warga masyarakat Desa, sekalian menikmati paket-paket yang sudah ada.

Gambar 2. dibawah ini adalah pelatihan tari baik tradisional dan kontenporer, yang dilatih oleh UKM Tari Universitas dhyana Pura.

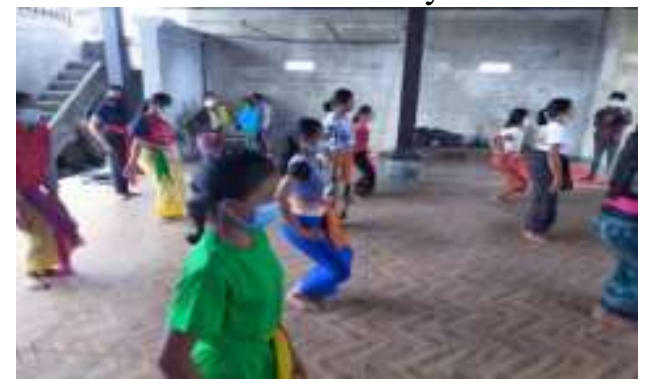

Gambar 2. Pelatihan Tari

Pemuda Desa Catur banyak memiliki potensi dan talenta, namun perlu diberikan pendampingan untuk pemudi yang ingin belajar tari kontemporer dan tradisional tersebut. Keterbatasan pengetahuan ini terlihat melalui pre test dan post test sebagaimana terlihat pada grafik 3 berikut ini.

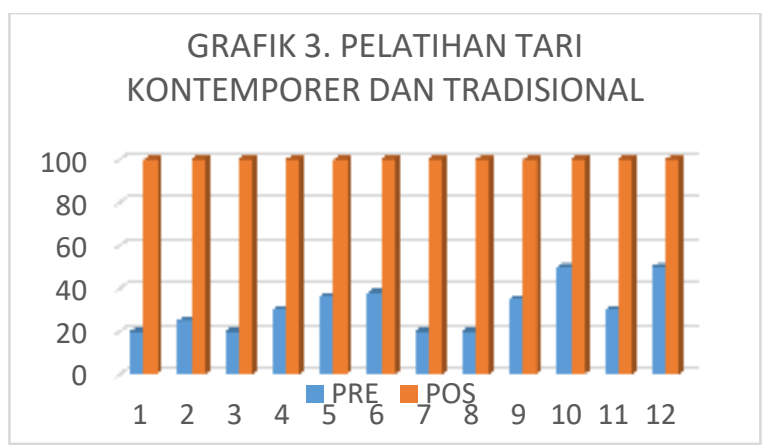

Grafik 3. Peningkatan Pengetahuan Pemudi tentang Tari

(Sumber: Analisis Tim PKM, 2021)

Pengetahuan anggota Pemudi Desa Catur terhadap pengenalan tari tradisional dan kontemporer menunjukkan peningkatan yang lebih baik. Jumlah anggota Pemudi Desa Catur yang memberikan respon pada saat pre test dan post test sebanyak 12 orang. Rata-rata selisih $50-55 \%$ terjadi peningkatan sebelum dan sesudah pelatihan. Artinya, anggota Pemudi Desa Catur mengalami peningkatan pengetahuan tentang manfaat pelatihan tari bagi pemudi di Desa Catur. Peningkatan pengetahuan ini berguna bagi pemudi agar bisa menyambut tamu wisatawan nusantara atau mancanegara.

Tim pengabdi undhira sudah merencanakan 
pemudi yang telah belajar tari untuk tampil di acara Dies Natalis Universitas Dhyana Pura, agar memiliki kepercayaan diri, namun karena ada surat edaran baik dari Gubernur Bali dan Rektor Universitas Dhyana Pura, maka di batalkan. Semoga setelah PPKM darurat ini kami bisa merencanakan pemudi desa pentas baik di dalam maupun di luar desa agar pemudi ini memiliki Percaya diri yang baik.

\section{Pelatihan Fotografi dan Penggunaan Digital Marketing (DIGIMART)}

Tahap pelatihan merupakan tindak lanjut dari program sosialisasi. Program pelatihan ini dapat diuraikan sebagai berikut:

\section{Melakukan pendampingan dan pelatihan Fotografi dan Digimart}

Pelatihan fotografi dan digimart dilakukan kepada kelompok yang telah terbentuk di Desa Catur Kintamani. Program ini diharapkan meningkatkan kemampuan Pengelola Penggunaan digital marketing Desa Catur Kintamani dalam menerapkan teknik promosi dengan menggunakan media sosial seperti facebook, twitter, WA, Line, dan sejenisnya. Pelatihan ini diharapkan Pengelola Penggunaan digital marketing Desa Catur Kintamani mampu mengelola secara terintegrasi tata kelola kuliner, homestay, rekreasi, aktivitas wisata, pengelolaan keuangan koperasi desa. Program ini dilaksanakan oleh Tim PKM dan oleh mahasiswa manajemen dan D3 Manajemen Pemasaran Digital Undhira (Lihat Gambar 3)

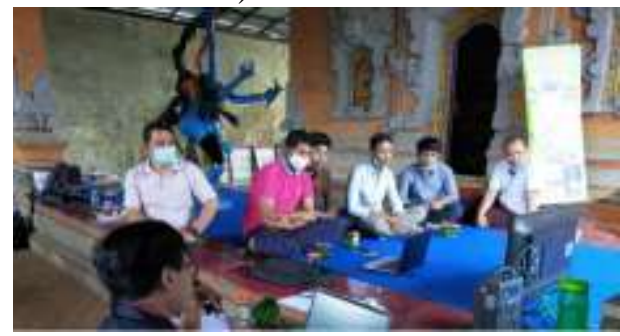

Gambar 3. Tim Anggota PKM memberikan Pelatihan Fotographi
Dibawah ini adalah Grafik 4 peningkatan sebelum dan setelah pelatihan yang diberikan oleh Tim Pengabdi Undhira.

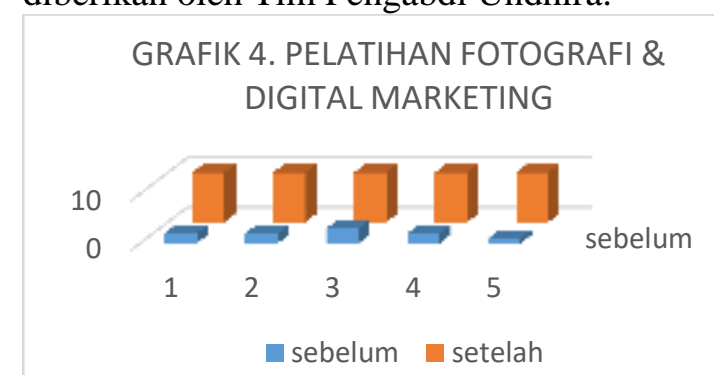

(Sumber: Analisis Tim PKM, 2021)

Grafik 4 diatas menunjukan bahwa ratarata ada peningkatan rata-rata $55-60 \%$ pelatihan sebelum dan sesudah pelatihan fotografi dan digital Marketing. Namun masih ada kendala dengan adanya pemberlakuan PKKM Darurat tersebut, yang rencana akan mengajak pemuda digital marketing (digimart) membuat Flayer dan Brosur belum terlaksana, sehingga untuk kegiatan selanjutnya akan di latih pembuatan brosur dan flyer sebagai bahan promosi Desa Wisata Catur, Kintamani. Pelatihan internet untuk para pemuda juga diberikan untuk mengatasi media promosi yang efektif dan efisien dalam bentuk Website. Program ini diharapkan Penggunaan digital marketing Desa Catur Kintamani memiliki profil yang lengkap tentang berbagai hal yang terkait dengan kepariwisataan dan aspek lain sebagai daya tarik wisata dan Pengelola Desa Wisata mampu membuat paket wisata yang terintegrasi dengan bidang usaha yang telah berkembang. Berikut website yang sudah disetting oleh Tim PKM yaitu: https://dwcaturkintamani.wordpress.com/

\section{Penyerahan Bantuan Alat}

Penyerahan bantuan alat ini dilaksanakan oleh tim pelaksana PKM dibantu oleh mahasiswa D3 Manajemen Pemasaran Digital Universitas Dhyana Pura. Gambar 14 Dibawah adalah Tim PKM menyerahkan bantuan alat berupa Laptop, Modem dan Mouse untuk Tim Digital Marketing Desa Catur Kintamani, Bangli.

\section{Kontribusi Mitra terhadap pelaksanaan}


Mitra memberikan akses bagi Tim Pelaksana untuk kegiatan pelatihan dan pendampingan kepada Tim Pemuda, dan kelompok sadar wisata. Mitra berpartisipasi secara aktif pada setiap kegiatan yang diberikan dan memberikan respon positif dengan menunjukkan antusias pada pelatihan digital marketing. Mitra hadir 90\% di setiap kegiatan. Kepala desa Pak Pande Wayan Sukarata menyatakan bangga dan senang dengan adanya bantuan yang difasilitasi oleh tim PKM karena mempermudah pembuatan website, integrasi potensi wisata, mempertahan budaya lokal melalui tarian baik tradisional dan kontemporer, Pelatihan Digital Marketing, serta pemasaran secara digital serta kewirausahaan.

\section{FAKTOR YANG MENGHAMBAT, FAKTOR YANG MENDUKUNG, DAN TINDAK LANJUT}

\section{Faktor yang Menghambat/ Kendala}

Pelaksanaan Program Kemitraan Masyarakat (PKM) berjalan dengan baik walaupun ada kendala-kendala yang dihadapi tim dalam pelaksanaan kegiatan PKM. Tim pengabdi baru memulai kegiatan di awal bulan April 2021 dengan menyusun program kerja dan sosialiasai kegiatan bersama mitra. Hal ini disebabkan karena terjadinya pandemi Covid-19. Kendalakendala yang dihadapi tim selama melaksanakan kegiatan yaitu:

\section{Proses pemesanan alat \& pengiriman alat "agak Lama".}

Didalam proses pemesanan dan pemberian Alat kepada Mitra khususnya Papan nama yang agak lama. Dengan diberlakukan PPKM darurat berpengaruh secara tidak langsung kepada Tim PKM dalam pembelian Alat seperti Papan Nama Pusat Informasi, dimana karyawannya banyak yang libur (di rumahkan), sehingga mereka bekerja dengan sumber daya manusia yang terbatas, begitu juga pengelasan besi dan kami harus bersabar. Namun Untuk Pembelian Laptop dan Modem, tidak ada kendala. Proses pengiriman alat dari Denpasar dengan membawa Papan nama yang cukup besar, apalagi sopir belum pernah ke Desa Catur Bangli, sehingga memakan waktu yang lama, sehingga menyebabkan tertundanya kegiatan sampai barang tersebut tiba di tempat mitra.

\section{Pemberlakukan PPKM Darurat, membatasi Ruang Gerak Tim}

Dengan Diberlakukannya PKKM Darurat ini, agak sulit Tim Pengabdi melakukan Evaluasi, Monitoring, ke Desa Catur karena ada surat edaran Gubernur Bali dan juga surat Edaran Pak Rektor Universitas Dhyana Pura untuk work from Home dan dilarang berpergian ke luar daerah. Sehingga masih tertunda beberapa kegiatan. Semoga setelah PPKM Darurat ini, Tim PKM bisa melanjutkan kegiatan, atau bisa juga dengan media online (zoom).

\section{Faktor yang Mendukung}

Faktor yang menjadi pendukung pada kendalakendala yang terjadi kegiatan PKM ini adalah dukungan dari mitra, LPPM dan Universitas Dhyana Pura. Mitra selalu mendukung pelaksanaan PKM dengan memberikan segala informasi yang diberikan oleh tim pengabdi. Tim pengabdi dan mitra selalu berkoordinasi, sehingga kegiatan dapat dilaksanakan dengan lancar.

\section{Solusi dan Tindak Lanjutnya}

Kendala yang dihadapai oleh tim pengabdi bisa diatasi dengan mengatur jadwal pelaksanaan. Pelaksanan yang tidak menggunakan alat-alat yang belum sampai ke tempat mitra, didahulukan pelaksanaannya.

\section{Rencana Selanjutnya}

Pelaksanaan kegiatan pengabdian kepada masyarakat sudah terlaksana $70 \%$, mulai dari menyusun konsep pengabdian hingga tahap 
pendampingan mitra. Adapun kegiatan rencana selanjutnya adalah sebagai berikut:

1. Rapat Kerja Penyiapan Kegiatan

2. Sosialisasi Kegiatan Dengan Mitra

2. Pelatihan dan Pendampingan Pembuatan Brosur dan Flayer Pemasaran Desa Wisata Catur.

3. Pelatihan Kewirausahaan Dengan Membuat Frame Foto Dalam Botol agar Tamu bisa mengingat Desa Catur

4. Pelatihan Membuat Thai Tea Untuk Memingkatkan Pendapatan Dan Kualitas Kesejahteraan Masyarakat Catur.

5. Pelatihan Pemasangan Konten di Instagram, Facebook dan whats up

6. Video Kegiatan

7. Publikasi di Media Cetak

8. Publikasi Media online

9. Evaluasi, Publikasi dan Pelaporan Kegiatan

\section{Langkah-Langkah strategis untuk realisasi selanjutnya}

Langkah-langkah strategis untuk reliasasi selanjutnya adalah:

1. Pelatihan Kewirausahaan Frame Foto Dalam Botol sebagai Cinderamata

2. Pelatihan Pembuatan Thai Tea untuk meningkatkan Pendapatan Warga Desa Catur

3. Monitoring \& evalusi kegiatan Memonitoring dan mengevaluasi sejauh mana keberhasilan pelaksanaan program dengan melihat secara langsung kemahiran mitra dalam penggunaan alat serta melakukan evaluasi terhadap kendala-kendala yang dialami mitra dalam melaksanakan program.

4. Membuat Buku Ber ISBN di penerbit "Deepublish".

5. Pelaporan akhir
Membuat laporan akhir untuk dimasukkan ke dalam simlitabmas.

\section{KESIMPULAN DAN SARAN}

\section{Kesimpulan}

Pelaksanaan Program Kemitraan Masyarakat (PKM), Penggunaan Digital Marketing Dalam Pengembangan Desa Wisata Catur, Kecamatan Kintamnai, Kabupaten Bangli berjalan sesuai dengan yang diprogramkan oleh tim PKM.

1. Mitra sudah belajar tentang pentingnya pusat informasi dan visitor centre serta sudah mendapatkan alat Papan nama Pusat Informasi di depan Kantor Desa.

2. Mitra sudah memiliki website https://dwcaturkintamani.com/ sehingga bisa dipakai untuk Promosi Desa Catur, Aplikasi Editor video kinemaster dan Akun media sosial Desa Kintamani.

3. Mitra sudah belajar potensi-potensi wisata di desa catur yang akan diintegrasikan menjadi Paket wisata. Sehingga akan menjadi sarana dalam promosi dan akan dibuatkan digital marketing.

4. Mitra mengumpulkan dokumen-dokumen untuk mendaftarkan izin P-IRT

5. Mitra sudah bisa Menari baik tari tradisional dan kontemporer yang akan dipakai sebagai penyambut tamu saat kunjungan wisatawan. Yang Nantinya akan diintegrasikan dalam brosur dan flyer sbg alat promosi desa catur Kintamani.

6. Pengetahuan Mitra meningkat dan Ketrampilan juga meningkat.

\section{Saran}

Saran yang dapat diberikan pada kegiatan PKM ini adalah: 
1. Diberikan alat-alat penunjang lainnya yang dapat mendukung proses pengintegrasian potensi wisata menjadi paket wisata.

2. Melakukan inovasi produk digital lainnya agar bisa melakukan promosi dimedia sosial.

\section{Ucapan Terimakasih}

Trimakasih kepada Kemendikbud-Ristek yang telah mendanai pengabdian kami tahun 2020, Terimakasih juga kepada Rektorat Universitas Dhyana Pura, LPPM Universitas Dhyana Pura atas dampingannya.

\section{DAFTAR PUSTAKA}

Agus Hari Wibowo, Diah Kristina. 2018. Efektivitas Penggunaan Bahasa Inggris Dalam Media Promosi Pariwisata Solo Raya Menuju Pembangunan Sistem Online Tourism Promotion. Journal Cakra Wisata Vol 19 Jilid 22018.

Ari, K.A., Yudana, I.M., Pursika, I.N. 2015. Budaya Hindu Yang Masih Digunakan Setelah Terjadinya Proses Peralihan Agama Hindu Menjadi Kristen (Study Kasus Di Desa Blimbingsari, Kecamatan Kintamani, Kabupaten Bangli). Jurnal Jurusan Pendidikan PKn, 3(1).

Dermawan Waruwu, Et Al. Pengembangan Tanaman Herbal Sebagai Destinasi Wisata Di Desa Catur, Kintamani, Bali. Makassar: Universitas Hasanudin. Jurnal PKM Vol 4 No 12020.

Dinda Sekar Puspitarini, Reni Nuraeni. Pemanfaatan Media Sosial Sebagai Media Promosi (Studi Deskriptif pada Happy Go Lucky House). Jurnal Common Vol 3 Nomor 1 Juni 2019.

Edwin Permana. 2009. Thesis Integrasi Pengembangan Wisata Pantai Dan Permukiman Nelayan Di Pesisir Barat Kabupaten Bengkulu Selatan Dalam Rangka Konservasi Alam. Surabaya: Instititute Sepuluh November.
I Nyoman Sukra Adinatha, Et Al. Pura Panyagjagan Di Desa Pakraman Catur, Kintamani, Bangli, Bali (Latar Belakang Sejarah, Fungsi Pura Dan Potensinya Sebagai Media Pendidikan Multikultur Di Sekolah Menengah Pertama Dan Masyarakat). Singaraja: Universitas Pendidikan Ganesha. Vol 2 No 3.2014.

Mandal, P. and Vong, J., 2015. Development of Tourism and the Hospitality Industry in Southeast Asia. Singapore: Springer.

Putu Chris Susanto, Et Al. Pendampingan Kelompok Sadar Wisata Desa Catur Kintamani Menuju Desa Wisata Yang Kekinian. Prosiding SINAPTEK 2 November 2018. Bali: UDHIRA Bali.

Ruspendi, Junaedi I Wayan., Utama, I.G.B.R., 2017.Motivasi Wisatawan Mengunjungi Desa

Utama, I.G.B.R., Ruspendi, Junaedi I Wayan., 2020. Membangun Pariwisata dari Desa: Desa Wisata Warisan Budaya Jatiluwih, Penebel, Tabanan, Bali. Yogyakarta: Deepublish.

Utama, I.G.B.R., 2015. Pengantar Industri Pariwisata. Yogyakarta: Deepublish.

Utama, I.G.B.R. 2007. Landscape as an Outdoor Recreation Form (Case Study the Netherlands and Bali, Indonesia). Available at SSRN 2553138.

Utama, I.G.B.R. 2007. Experience Marketing at Eka Karya Botanical Garden Bali. Available at SSRN 2628177.

Utama, I.G.B.R. 2014, October. Agrotourism as an Alternative Form of Tourism in Bali Indonesia. In The International Conference on Sustainable Development March (Vol. 6, p. 2012). 
Utama, I.G.B.R. 2015. Leisure and Tourism on Quality of Life. Available at SSRN 2629774.

Utama, I.G.B.R., 2017. Pemasaran Pariwisata. Yogyakarta: Andi

Widiyanto, D., Purwo Handoyo, J. and Fajarwati, A., 2008. Pengembangan Pariwisata Perdesaan (Suatu Usulan Strategi bagi Desa Wisata Ketingan). Bumi Lestari, 8(2).

Wuni, I.A.K.N., Sendratari, L.P., Hum, M., Margi, I.K. and Si, M., 2014. Gereja Pniel Di Desa Blimbingsari, Bangli, Bali (Sejarah Pendirian Dan Potensinya Sebagai Sumber Belajar Sejarah Di Sma). Jurnal Widya Winayata, 2(1). 